\title{
Distribution of Nitrogen in Root Materials of Blue Grama
}

\section{FRANCIS E. CLARK AND MARILYN CAMPION}

Highlight: Root materials of blue grama were compartmentalized into three categories-live, senescent, and detrital. Their mean $N$ contents were $0.89,1.90$, and $2.56 \%$, respectively. For each root category there were significant differences both with soil depth and time of sampling. Soil $N$ differed significantly with depth but not across dates of sampling. The standing crop of root $N$ was found to occur largely in senescent and detrital materials. Compartmentalization of the plant $N$ belowground as well as that aboveground should promote more successful simulation of root growth dynamics and nutrient flows.

Authors are microbiologist, Agricultural Research Service, Fort Collins, Colo.; and statistician, Natural Resource Ecology Laboratory, Colorado State University, Fort Collins.

The work is a contribution of the Agr. Res. Serv., U.S. Department of Agriculture, in cooperation with the Colorado State Univ. Experiment Station, Fort Collins. Scientific Journal Series Paper 2081. Manuscript received May 29, 1975.
Comprehensive data are available on the total amount of root materials in various grasslands and on biomass responses to stresses and perturbations (Sims and Singh, 1971). Although aboveground biomass is readily separable into four or more compartments (standing green, standing yellow or recent dead, old dead, and one or several types of litter), separating gramineous roots into even two compartments, live and dead, is time-consuming and not routinely undertaken. Measurements of root nutrient contents are commonly based on composite samples of the total root biomass. Recently proposed simulations of carbon and nutrient flows in shortgrass prairie have emphasized the paucity of information concerning the belowground ecosystem (Marshall, 1975). That in many grasslands the major portion of the total standing crop is belowground further stresses the importance of an adequate data base for describing root and nutrient dynamics 
belowground.

A detailed study of roots of blue grama (Bouteloua gracilis) has recently been reported by Ares (1976). He used morphological characteristics to classify root materials into five categories; his interest was primarily in root growth dynamics and not in nutrient content. Concurrently with Ares work and also using shortgrass prairie in northeastern Colorado, Clark (1975) conducted an isotopic nitrogen study in which a pulse application of ${ }^{15} \mathrm{~N}$ was monitored as it'moved into and from different parts of blue grama plants. Clark's study involved only three root categories; these, however, could be separated by gross techniques not involving individual examination of each root or root segment. The current study concerns the $\mathrm{N}$ content of categories of root mateirals collected during the course of the ${ }^{15} \mathrm{~N}$ experiment. The data are based on 11 samplings spaced over three growing seasons.

\section{Study Site and Methodology}

The study area was grassland located $56 \mathrm{~km}$ northeast of Fort Collins, Colo. The site has been described in some detail by French (1971). The soil is Ascalon fine sandy loam, a Mollisol, with the parent material a fluvial outwash, primarily granitic. Rooting depth exceeds $100 \mathrm{~cm}$, to which the estimated available water storage is $11 \mathrm{~cm}$. The annual precipitation ranges from 25 to $38 \mathrm{~cm}$. Blue grama commonly constitutes 50 to $95 \%$ of the vegetative cover. Fringe sage (Artemisia frigida) and pricklypear (Opuntia polycantha) are usually secondarily dominant components.

Mini-enclosures of blue grama were established in May 1971. Open-ended steel cylinders $(20 \mathrm{~cm}$ in diameter and $40 \mathrm{~cm}$ long) were driven to nearly ground level into undisturbed blue grama. Eleven destructive samplings were made during the 1972-1974 growing seasons. In sampling, cylinders in triplicate were excavated together with their soil (c. $15 \mathrm{~kg}$ ) and herbage content, and transported to a laboratory bench. Aboveground herbage was clipped to the soil surface and each soil column separated into its 0 to 10,10 to 20 , and 20 to $36 \mathrm{~cm}$ segments. Three categories of root materials were collected from each of three profile depths. The live-root category consisted of nonbrittle, lightly colored (ivory to yellowish) roots obtained by handpicking. Senescent roots were the generally brittle, shorter segmented, and darker colored roots obtained partly by handpicking and partly by air-suction pickup from thinly spread soil. The detrital category comprised the fine particles recoverable by water flotation from soil following the hand and air-suction removals.

Root dry weight, organic $\mathrm{C}$, total $\mathrm{N}$, and ash content were measured. Carbon was determined by combustion in an automated electric furnace, and nitrogen by standard micro-Kjeldahl procedure. Because two of the three categories of roots were dry-sorted and unwashed before analyses, ash content frequently exceeded $50 \%$. The standard correction of $\mathrm{N}$ percentage to ash-free basis was considered to be misleading since such correction included the $\mathrm{N}$ content of any adhering soil. Therefore, root $\mathrm{N}$ percentages are reported on a modified ash-free basis. The organic $\mathrm{C}$ value of a root sample was used to fractionate that sample into a soil and a root component. The soil $\mathrm{N}$ content, as determined from a root-free aliquot from the corresponding profile depth, was used to determine the amount of $\mathrm{N}$ in the gross root sample attributable to the soil fraction; then the remainder was attributed to the root fraction.

The $\mathrm{N}$ percentages determined were subjected to analyses of variance, which for the roots included two-way factorial analysis for each category across depths and dates and three-way repeated measures analysis across depth, root category, and dates. When significance was encountered at the 0.05 level, Tukey's $Q$ value for $\alpha=0.05$ was calculated (Snedecor and Cochran, 1959).

\section{Results and Discussion}

Table 1 presents the mean $\mathrm{N}$ contents of the three categories of root materials at three profile depths on 11 sampling dates. Also shown are the $\mathrm{N}$ contents of the soil profiles from which the roots were collected. Mean soil $\mathrm{N}$ content for the 0 to 10,10 to 20 , and 20 to $36 \mathrm{~cm}$ depths were $0.093,0.079$, and $0.072 \%$. These differences were significant; the $Q$ value was 0.006 . Mean N contents of the three root categories (live, senescent, detrital) differed widely; the $\mathrm{N}$ values were $0.89,1.90$, and $2.56 \%$, respectively. Such a progression with senescence and decomposition occurs because

Table 2. Mean $\mathbf{N}$ content for three root categories at three profile depths.

\begin{tabular}{lccc}
\hline $\begin{array}{c}\text { Root } \\
\text { category }\end{array}$ & $\begin{array}{c}\text { Profile } \\
\text { depth } \\
(\mathrm{cm})\end{array}$ & $\begin{array}{c}\mathrm{N} \\
\text { content } \\
(\%)\end{array}$ & $\begin{array}{c}\mathrm{Q} \\
\text { value }\end{array}$ \\
\hline Live & $0-10$ & 1.081 & 0.093 \\
& $10-20$ & 0.812 & \\
Senescent & $20-36$ & 0.769 & \\
& $0-10$ & 2.139 & 0.117 \\
& $10-20$ & 1.866 & \\
Detrital & $20-36$ & 1.642 & \\
& $0-10$ & 2.658 & 0.159 \\
& $10-20$ & 2.550 & \\
\hline
\end{tabular}

Table 1. Nitrogen content (\%) of blue grama roots (modified ash-free basis) and of the soil from which the roots were collected.

\begin{tabular}{|c|c|c|c|c|c|c|c|c|c|c|c|}
\hline & $\begin{array}{c}\text { Mar. } 29 \\
1972\end{array}$ & $\begin{array}{c}\text { May } 10 \\
1972\end{array}$ & $\begin{array}{c}\text { June } 12 \\
1972\end{array}$ & $\begin{array}{c}\text { Aug. } 8 \\
1972 \\
\end{array}$ & $\begin{array}{c}\text { Oct. } 3 \\
1972\end{array}$ & $\begin{array}{c}\text { Mar. } 7 \\
1973\end{array}$ & $\begin{array}{c}\text { June } 13 \\
1973 \\
\end{array}$ & $\begin{array}{c}\text { Aug. } 3 \\
1973 \\
\end{array}$ & $\begin{array}{c}\text { Oct. } 12 \\
1973 \\
\end{array}$ & $\begin{array}{c}\text { June } 18 \\
1974 \\
\end{array}$ & $\begin{array}{r}\text { Oct. } 9 \\
1974 \\
\end{array}$ \\
\hline \multicolumn{12}{|l|}{ Live roots } \\
\hline $0-10 \mathrm{~cm}$ & 1.375 & 1.263 & 1.043 & 1.108 & 0.867 & 1.074 & 1.073 & 0.900 & 1.212 & 1.089 & 0.888 \\
\hline $10-20 \mathrm{~cm}$ & 0.847 & 0.744 & 0.796 & 0.731 & 0.777 & 0.863 & 0.896 & 0.710 & 0.955 & 0.750 & 0.862 \\
\hline $20-36 \mathrm{~cm}$ & 0.906 & 0.624 & 0.764 & 0.848 & 0.721 & 0.960 & 0.776 & 0.674 & 0.883 & 0.597 & 0.711 \\
\hline \multicolumn{12}{|l|}{ Senescent roots } \\
\hline $0-10 \mathrm{~cm}$ & 2.340 & 2.032 & 1.993 & 2.073 & 1.938 & 2.358 & 2.316 & 2.114 & 2.298 & 2.020 & 2.050 \\
\hline $10-20 \mathrm{~cm}$ & 1.737 & 1.839 & 1.896 & 1.920 & 1.363 & 1.943 & 1.080 & 1.705 & 2.200 & 1.902 & 1.936 \\
\hline $20-36 \mathrm{~cm}$ & 1.502 & 1.630 & 1.500 & 1.527 & 1.783 & 1.678 & 1.909 & 1.633 & 1.858 & 1.419 & 1.624 \\
\hline \multicolumn{12}{|l|}{ Detrital roots } \\
\hline $0-10 \mathrm{~cm}$ & 2.210 & 2.750 & 2.729 & 2.355 & 2.387 & 2.880 & 3.140 & 2.713 & 2.788 & 2.545 & 2.742 \\
\hline $10-20 \mathrm{~cm}$ & 2.304 & 2.825 & 2.876 & 2.485 & 1.989 & 2.618 & 2.973 & 2.406 & 2.678 & 2.347 & 2.546 \\
\hline $20-36 \mathrm{~cm}$ & 2.314 & 2.371 & 2.763 & 2.298 & 1.907 & 2.661 & 2.446 & 2.500 & 2.717 & 2.269 & 2.804 \\
\hline Soil & & & .094 & .098 & .089 & .095 & .094 & .096 & .087 & .079 & .093 \\
\hline $10-20 \mathrm{~cm}$ & .079 & .079 & .081 & .084 & .077 & .084 & .076 & .075 & .080 & .081 & .075 \\
\hline $20-36 \mathrm{~cm}$ & .070 & .069 & .072 & .071 & .064 & .077 & .068 & .072 & .074 & .086 & .064 \\
\hline
\end{tabular}


carbon is lost as carbon dioxide while $\mathrm{N}$ is retained in the substrate.

Within each root category, the root $\mathrm{N}$ decreases with profile depth (Table 2). This decrease is apparently a function of the soil $\mathrm{N}$ content inasmuch as the ratios for root $\mathrm{N}$ :soil $\mathrm{N}$ at each depth are surprisingly constant. For live roots, the ratios are $11.6,10.3$, and 10.7. For senescent root $\mathrm{N}$ :soil $\mathrm{N}$, the ratios $(23.0,23.6$, and 22.8$)$ are also closely similar. The detrital root $\mathrm{N}$ :soil $\mathrm{N}$ ratios are slightly less uniform-28.6, 32.3, and 34.2.

There were no significant differences across sampling dates in soil $\mathrm{N}$ content within any of the three profile depths, but there were significant differences with time in the $\mathbf{N}$ content of the three root categories. For live roots, such change with time was expected. It is well known that plant $\mathrm{N}$ concentration changes with growth stage. In the current study, the $\mathrm{N}$ content not only of live roots but also of senescent and detrital roots changed significantly within the growing season. Abiotic factors affect not only the transfer of root materials from the live root category but also the activity of decomposer organisms and, in turn, the $\mathrm{N}$ content of senescent and detrital roots.

Based on $\mathrm{N}$ contents and biomass determined in this study, the total $\mathrm{N}$ in root materials to a depth of $36 \mathrm{~cm}$ for blue grama on the site specified is $33 \mathrm{~g} / \mathrm{m}^{2}$. Distribution of this nitrogen according to categories of roots and profile depths is shown in Table 3 . The $33 \mathrm{~g} / \mathrm{m}^{2}$ of root $\mathrm{N}$ represented $79 \%$ of the total plant $\mathrm{N}$ recovered. The remaining $21 \%$ was accounted for in green herbage $(3.5 \%)$, in aboveground litter and standing dead $(6.0 \%)$, and in crowns $(11.5 \%)$. There were $380 \mathrm{~g} / \mathrm{m}^{2}$ of soil $\mathrm{N}$ to a $36-\mathrm{cm}$ depth, therefore soil $\mathrm{N}$ accounted for $92 \%$ of the plant-soil total.

The current study has shown that the root materials in grassland can be compartmentalized successfully and that significant differences exist in the $N$ contents of the root categories separable. Compartmentalization of the below-
Table 3. Distribution of nitrogen in three categories of root materials of blue grama.

\begin{tabular}{lrrrr}
\hline \multirow{2}{*}{$\begin{array}{l}\text { Root } \\
\text { category }\end{array}$} & \multicolumn{4}{c}{ Profile depth } \\
\cline { 2 - 5 } & $0-10 \mathrm{~cm}$ & $10-20 \mathrm{~cm}$ & $20-36 \mathrm{~cm}$ & $0-36 \mathrm{~cm}$ \\
\hline Live & 2.23 & 0.28 & 0.17 & 2.68 \\
Senescent & 14.09 & 1.87 & 1.18 & 17.14 \\
Detrital & 7.63 & 2.66 & 3.07 & 13.36 \\
Total & 23.95 & 4.81 & 4.42 & 33.18 \\
\hline
\end{tabular}

ground additionally to that of the aboveground herbage should permit more successful simulation of root growth, decompositional changes and nutrient flows.

\section{Literature Cited}

Ares, J. 1976. Dynamics of the root system of blue grama. J. Range Manage. 29:208-213.

Clark. F. E. 1975. Partitioning of added isotopic nitrogen in a blue grama grassland. In: The belowground ecosystem-A synthesis of plant-a ssociated processes. (J. K. Marshall, Ed.) (In press)

French, N. R. (Ed.). 1971. Preliminary analysis of structure and function of grasslands. Range Sci. Dep. Sci. Ser. No. 10, Colorado State Univ., Fort Collins. 387 p.

Marshall, J. K. (Ed.). 1975. The belowground ecosystem-A synthesis of plant-associated processes. Dowden, Hutchinson \& Ross, Philadelphia. (In press)

Sims, P. L., and J. S. Singh. 1971. Herbage dynamics and net primary production in certain ungrazed and grazed grasslands. p. 59-124. In: Preliminary analysis of structure and function in grasslands. (N. R. French, Ed.) Range Sci. Dep. Ser. No. 20, Colorado State Univ., Fort Collins.

Snedecor, G. W., and W. G. Cochran. 1969. Statistical methods. Iowa State Univ. Press, Ames. 593 p. 